\title{
10
}

\section{Blasphemy and the art of the political and devotional}

\section{Christopher Braddock}

\begin{abstract}
A breakdown in the unity of state and church has altered the context in which blasphemy might be understood. Rather than viewing blasphemous libel as intrinsically linked through the Ecclesiastical courts within the unity of State and Church, the emphasis has shifted to the individual in society whose freedom of artistic expression is constrained instead by the secular laws of defamation and obscenity. In this light, artists such as Andres Serrano and Tania Kovats embrace a freedom to use dramatic and visually confronting binary oppositions in their works of art. ${ }^{l}$ Andres Serrano juxtaposed the crucifix with urine, and Tania Kovats, a statuette of the Virgin Mary with a condom. Such iconography provokes the possibility that these artworks might function as simultaneously political and devotional: powerfully critical of church institutions, while aesthetically operating as symbols that evoke reverence. In this context it is significant that, in the debates that followed the controversies surrounding these works of art, the arts establishment emphasised the division between church and state in justification of the artists' right to freedom of expression, and the difference between temple and museum was highlighted in discussion about the contextual setting of the museum as a place in which 'blasphemy' could not occur. Artistic intention, and the context in which these works are witnessed, are debated as factors in determining the possibility of blasphemy within the divide of state and church, museum and temple.

In this chapter I will argue that interpretations of graphic Medieval images of the body that avoid binary opposition are useful in a reappraisal of the controversy surrounding artworks such as Serrano's Piss Christ and Kovat's Virgin in a Condom. This raises questions about the role of devotional images. Do they exist primarily to reinforce the strict teachings of the church or can they be used to examine those beliefs? If we accept the latter as a possibility, could these confrontational images signify divine revelation in the body, the very essence of the Incarnation?
\end{abstract}




\section{Locating 'blasphemy' in the polemical}

The beginning of the twenty-first century has brought into focus issues of right-wing religious fundamentalism (be it Islamic or Christian) even more sharply. The dangers and dilemmas of essentialist religious paradigms have joined a list of vitally important global issues to be reckoned with, arguably as important as global poverty and global warming. It is in this light that bearing-witness to blasphemy becomes part of a debate about tolerance within a pluralistic society.

As Kyla McFarlane described in the catalogue for the exhibition Votive: Sacred and ecstatic bodies, ${ }^{2}$ in the last decade, Australia and New Zealand bore witness to artwork seemingly crossing the boundaries that constitute blasphemy:

In October 1997, Melbourne's National Gallery of Victoria closed an exhibition of works by American artist Andres Serrano after two physical attacks by members of the public on his photograph Piss Christ (1987). This incident followed earlier claims by Christian groups and senators in the USA that the work was indecent and obscene. ${ }^{3}$ Serrano had received funding from the National Endowment for the Arts and, following a complaint from the American Family Association, Senator Jesse Helms proposed that indecent or offensive works should not continue to receive funding. New York Senator Alphonse D'Amato also condemned the work in Congress. His outrage, and that of Helms, was publicly echoed by many constituents. ${ }^{4}$

Serrano's work is a photographic enlargement of a small commercially produced crucifix immersed in Serrano's own urine. Without the title of the work to indicate the substance of piss used to create the image, the viewer might revel in the sublimely romantic connotations of a misty atmospheric sky at sunset striking at the heart of the crucifixion story with its hope of resurrection after death. But Serrano's titling ensures that the viewer has to confront the dilemma that this is a vat of urine.

A severing of the unity of state and church has reinforced the freedoms of the individual to roam across boundaries making a question of ownership of religious symbols and their employment difficult to answer. The Catholic Archbishop of Melbourne, Dr. George Pell, who considered Piss Christ blasphemous, applied unsuccessfully for a Supreme Court injunction to prevent the National Gallery of Victoria from exhibiting the work. Justice Harper cast doubt on the need for the common law of blasphemous libel in Victoria, saying that Australia 'need not bother with [it]' because contemporary Australia is a pluralist, tolerant society. ${ }^{5}$ Justice Harper distinguished the Victorian position from the English law stating that blasphemous libel is 'an anachronism of English history from a time when the State was intrinsically linked with the Church, 
through the Ecclesiastical courts, and the unity of State and Church was not transported to the Australian Colony. This position is supported by the fact that Victoria does not recognise an established Church under section 116 of the Australian Constitution'. ${ }^{6}$ Now that the state and the church are no longer inseparable, the question of authority and how religious iconography is employed appears to shift to wider concerns of freedom and artistic expression as constrained by the laws of defamation and obscenity. A calculation of the level of offence experienced by the viewer moved to centre-stage.

McFarlane points to a similar reaction of public outrage with respect to Tania Kovat's Virgin in a Condom:

In a matter of days, Tania Kovats' Virgin in a Condom (1992) was stolen by a visitor to the Museum of Contemporary Art in Sydney. Exhibited as part of 'Pictura Britannica', a show of work by young British artists, it provoked numerous letters of protest and complaints from incensed Christians and Muslims when it toured to Te Papa/Museum of New Zealand the following year. ${ }^{7}$

Virgin in a Condom is a strikingly polemical work. On the one hand, the seven and a half centimetres tall mass-produced statuette is a religious object made for the purpose of evoking the Virgin Mary's divine intercession and has been covered with an object used, more or less exclusively, for covering erect penises or a variety of sex toys, such as 'butt-plugs'. Clearly, many viewers understood the work as presenting an analogy to the Virgin Mary as a dildo. As I will argue, a reappraisal of these binary interpretations might suggest that, on the other hand, the statuette is religiously shrouded or concealed, visually resembling a work such as Piero della Francesca's Madonna della Misericordia (circa 1445), in which the Madonna protects the people with her mantle. This condom as shroud evokes notions of the polarised role models for women within Catholicism: that women are unfairly torn between virgin and whore in the archetypal models of Mary, the Mother of God, and Mary Magdalene, the redeemed whore. As well as this, the sculpture strategically provokes discussion about the Catholic Church's prohibition of contraception by the use of condoms. Neither of these issues, by the way, had any prominence whatsoever in the New Zealand media coverage surrounding the controversy over Virgin in a Condom's presence in Te Papa. The lack of media coverage on these key issues highlights an assumption that artists intend to shock rather than engage in public debate. Such an assumption overlooks the possibility that artist's may intend to provoke public discussion on these issues, or to explore unconventional views on religion within a museum context. I will return to this point in discussing the role of the museum as providing a space for unconventional views of religion below.

The perceived polemical nature of the work contributed to Virgin in a Condom becoming, arguably, the most publicised work of art in the history of New 
Zealand, Tania Kovats would not reply to any invitation to participate in the exhibition Votive: Sacred and ecstatic bodies that I curated in Wellington in 2002. Her Australasian experience, which included receiving abusive mail and death threats, had been so traumatic that she wanted nothing more to do with us. Her representative, the London-based Asprey Jacque Gallery, indicated that the direction of her work was changing to the extent that another inclusion in a religious project would misrepresent the artist.

Arguments surrounding the accountability of public expenditure in public institutions such as galleries form strong undercurrents to these debates about the control and use of religious symbols. In contrast with the National Gallery of Victoria, Te Papa Tongerewa Museum of New Zealand stood their ground. They refused to remove Virgin in a Condom from the Pictura Britannica exhibition and backed their right to be an artistic conscience of society. In the words of the concept curator, Ian Wedde, the museum had to be a free space for several kinds of expression. It had to be available 'for the expression of divergent and controversial views' ${ }^{8}$ Some of these controversial views may be unorthodox religious or theological perspectives.

Serrano contends that Piss Christ stems from his religious upbringing, and that the work upholds his religious conviction that the body can be seen as a means for obtaining religious redemption. As Serrano puts it:

The photograph, and the title itself, are ambiguously provocative but certainly not blasphemous... My Catholic upbringing informs this work which helps me to redefine and personalise my relationship with God. My use of such body fluids as blood and urine in this context is parallel to Catholicism's obsession with 'the body and blood of Christ'. It is precisely in the exploration and juxtaposition of the symbols from which Christianity draws its strength. ${ }^{9}$

Who then, should decide whether something is blasphemous? The church or religious group who claims ownership and control, or the artists themselves?

One standard model for the interpretation of art involves consideration of the artist's intentions. Within a context of the divide between state and church and the concomitant freedom of the individual, such a model seems apt. Our knowing that Serrano sees himself as working within the parameters of his own faith seems to alter our immediate impression that this is a case of blasphemy. It is as though, given his Christian upbringing, Serrano feels entitled to use the religious images as he pleases, and that, as a Christian, he was incapable of blaspheming. This idea of membership giving entitlement to use images however you like raises questions about how 'membership' is determined, and whether there can be levels of membership and entitlement. 
A conflicting position about how we should interpret a work of art appeals to the conventional meaning of the symbols. If we read the image at face value, it is still his piss, a human by-product of waste not normally associated with the reverence of God. The media recently condemned American soldiers for the blasphemy of urinating on the Koran during the military campaign in Iraq. If this is clearly an act of blasphemy in relation to what is held sacred to Muslims, and was correctly interpreted as an attack on the sentiments of the Muslim prisoners they had captured, we would not expect a Christian to engage in a similar act with respect to their own faith. This raises the question of what role the gallery plays in providing a context for interpreting a work of art, and its appreciation.

\section{The context of witnessing blasphemy}

Is viewing Piss Christ in an art gallery different from contemplating or worshipping the image in a church? According to an institutional theory of art, the identification of something as art influences the manner in which something is interpreted. Such a theory of art is proposed by George Dickie where a 'work of art' must satisfy the dual conditions of an artefact made by 'a person who participates with understanding in the making of an artwork' together with a confirmation of its status as an artwork 'by some person acting on behalf of the Artworld'. ${ }^{10}$ According to Dickie both conditions are necessary to confirm the status of a work of art. From this perspective, does the institutional context of the museum reserve a place for artistic critique that is separate from those contexts within which we plausibly interpret something to be blasphemous? In other words, does it reserve a space that permits artists to manoeuvre across parameters of critique and devotion? This is a significant question as it has implications for the role of the gallery as providing a space for alternative views of religion and for the practice of religion.

Serrano's work can be compared to Ian Breakwell's Deep Faith (2001), which was included in the Votive exhibition. In Deep Faith, a slide projection features an X-ray of the throat of a woman who had swallowed a small crucifix which had lodged in her throat. Breakwell found the X-ray while he was an artist-in-residence at the Cardiff Anatomy Unit. The gradual and repeated dissolving of a second slide over the first featuring the words 'deep faith', a reference to the 1972 pornographic film Deep Throat, sexualises the work's imagery. This overlay of images hovers between acceptance of Christian doctrine, indeed an obsessive consumption of the Body of Christ, and the sexual act of fellatio. This reference plays on devotional allusions, toying with the notion of complete acceptance of Christian doctrine, while aligning this with a sexual act. The image also has a violent subtext, with the figure becoming an intrusive lodgement in the throat. As McFarlane comments: 
This association of the figure of Christ with the interior of the body also echoes Serrano's submersion of a similar figure in his own urine in Piss Christ. In both works, the body of Christ is strongly associated with the functioning of the human body, at the beginning and end of digestive process. In the former, the figure is taken into the throat and remains uncomfortably lodged there, whilst in the latter, it is associated with expulsion of waste. ${ }^{11}$

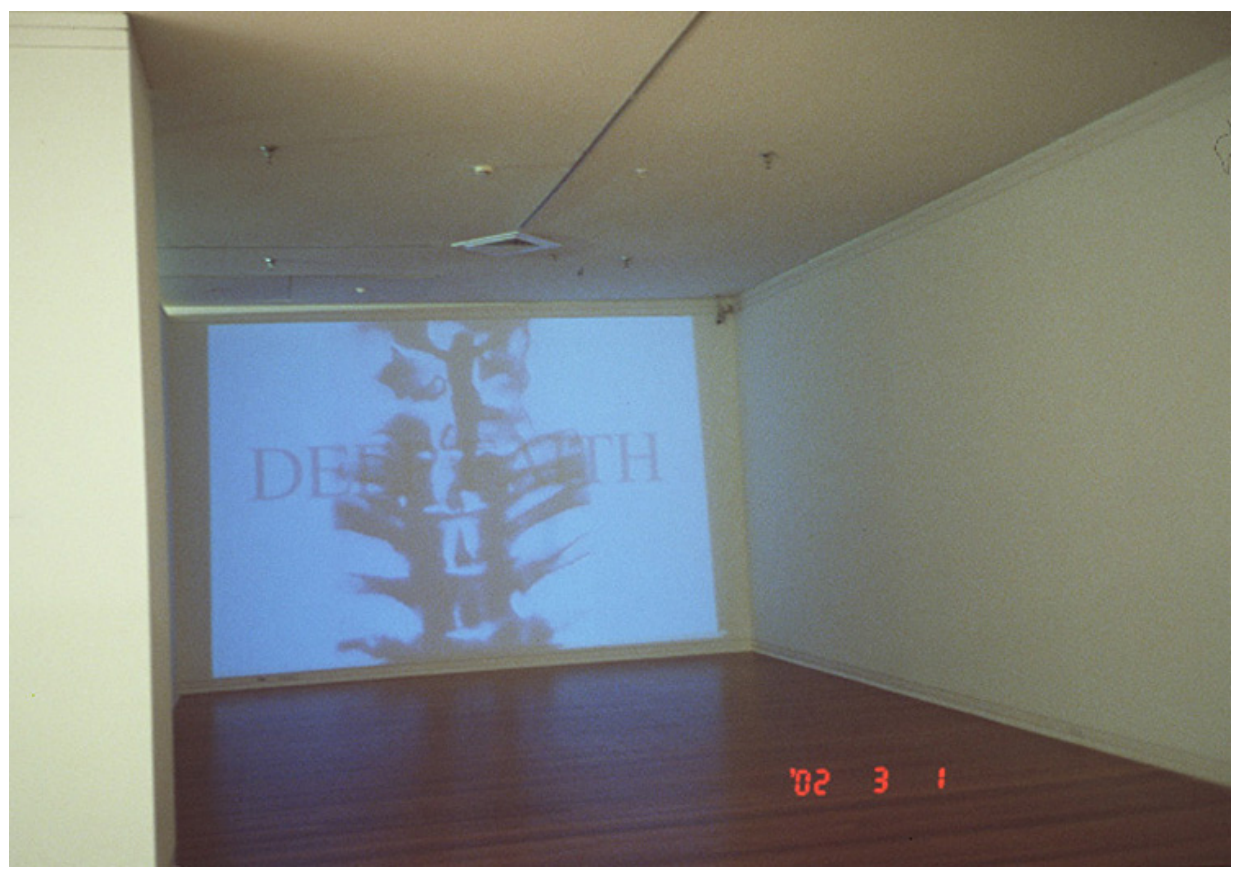

Ian Breakwell, Deep Faith, 2001, copyright The Estate of Ian Breakwell

Mediated by photographic processes and presented within the museum, do Piss Christ and Deep Faith operate outside of the realm of devotion, and only as a critique of the teachings of the Church? Do they, in other words, simply critique from the sidelines?

As an artist, the question of where these artworks are witnessed was on my mind when my work was included in an exhibition in New York City entitled The Divine Body. ${ }^{12}$ The venues for the exhibition covered an array of institutional settings. The gallery at Columbia, the Cathedral of St John the Divine, and a theological seminary: art, worship and pedagogy. The distribution of the art works seemed to have been dictated by economic imperative. Those of higher economic value, such as the Andres Serrano and the Eric Fischl, were provided with the security of the Columbia's gallery, while other works were spread out across the other venues. It occurred to me to ask: 'What would have happened if Piss Christ had been exhibited in St John the Divine?' There might be people 
who think Piss Christ is not blasphemous in a museum, but blasphemous in a place of worship. To the best of my knowledge the work has never been exhibited in a place of worship. But, would this be blasphemous? What would happen if my cibachrome photographs of naked tattooed models were exhibited in St John the Divine? These works explore white-trash inspired tattoos inscribed close to nipple, buttock and pubis, intimately photographed. The works aim to provoke a collision between the practice of tattoo outlawed within most Judaeo-Christian circles and an edification of the body.

And the question of placing Piss Christ in a church struck at the heart of a dilemma in viewing both Piss Christ and Virgin in a Condom. On the one hand, I see them as overly simplistic slogan-like artworks that are blasphemous in their collision of clearly defined sacred and profane imagery; I would not photograph the Koran floating in a pool of urine. And, on the other hand, my acceptance of an institutional theory of art inclines me to think of the context of the art gallery as a site of questioning and critique, not a site of devotional practice. Yet, Breakwell's aestheticisation of the image - projected in a dimly lit space and viewed against the organ music of the late French composer Olivier Messian clearly point to an atmosphere of reverence if not of devotion.

A conclusion that works of art accused of being blasphemous are so simply because they break religious dogma, or are exhibited in a sacred space, is problematic. The conclusion provokes questions about the role of religious symbols in ecclesiastical settings, and suggests that they exist primarily to reinforce the strict teachings of the church. A religious painting in a church could also examine or tease-out the nature of those beliefs. My earlier suggestion that the museum might reserve a place of artistic critique outside the realms of worship seems now too simplistic, and undermines the possibility of 'religious' art operating across the parameters of critique and devotion.

\section{Religious law and sacred bodies}

Ian Breakwell's video, The Sermon, 1984, which was also exhibited in the Votive exhibition, subtly explored interpretations of 'the law' in Catholic teaching and its relationship with the desires of the body. In so doing, Breakwell shifts our focus from a cleric reinforcing the law of the church to an individual overcome by a sense of blasphemy in how he occupies his own body. Kyla McFarlane writes in Votive:

The Sermon is...[a] sardonic commentary on the effects of the law as stated by the institutional voice, it takes the format of a television sermon in a book-lined study reminiscent of the set of Stars on Sunday. The speaker, a seated priest, begins by calmly reminding the viewer that we have erred and offended against 'the laws' and that clarification is needed regarding areas of guidance. As the monologue progresses, however, his 
avid pleasure in addressing the perverse and sinful becomes apparent, with the tone of the address moving from sage, fatherly advice to a frenzied tirade against the lusts of the flesh and original sin. The sermon is subject to a kind of leakage, as a perverse desire meets with the rigidity of the institutional voice...Breakwell's spoken text is littered with references to bodily fissures and seepages, such as 'the rupturing of membranes' during birth, or the leaking of sperm from a condom perforated with holes so that the marriage act can still be performed within the guidelines of the faith whilst collecting semen for laboratory tests. Or, finally, the gutting of the stomach of the depraved. Absurd and viscous, The Sermon ironically describes the impress of the body and its filthy excesses on the intellectual rigour of the law. In attempting to contain and restrain, the law itself becomes perverse and obsessive. By the video's end, desire and the law become blurred to the point of misrecognition. ${ }^{13}$

In the video, bodily function, and our relationship with the body, is inscribed with the categories of the pure and the impure. The body is thought of as a kind of temple, which requires us to treat it in a certain way. Yet the attempt to achieve purity is undermined by the body itself; its own secretions defile it.

Julia Kristeva argues that categories of abomination such as food taboos or corporeal alterations, topologically correspond to one's being able to have access to a place - the holy place of the Temple. Impurity, therefore, has a relationship to what happens outside the Temple. But this relationship is not contingent on a physical existence of the Temple: for Judaism, the Temple's function remained the same when the Temple was destroyed. ${ }^{14}$

Kristeva's notion of the Temple enfolds onto our own bodies, in biblical terms, the body as a Temple of the Holy Spirit: 'A mouth attributed to the anus: is that not the ensign of a body to be fought against, taken in by its insides. ${ }^{15}$ This describes a possibility for blasphemy and sacrilege in how we occupy our bodies individually, and by our relationship to other bodies. Seen from this perspective, Piss Christ contravenes the boundaries of the self's clean and proper body, just as Ian Breakwell's Deep Faith aligns throat and penis, as a symbolic protest against an intrusive moral theology.

\section{Beyond the dichotomies of abjection and transcendence}

Kristeva's project seeks to redeem the female body from categories of abomination, from existing outside the Temple, due to functions that include menstruation and lactation. And here it is helpful to imagine a fictitious artwork by Serrano that elucidates Kristeva's position, let us call it Menstrual Blood Christ. A crucifix submerged in menstrual blood indexes the sexualised female body, 
identified as abject, and describes a problematic position for women in relation to the holy place of the Temple.

Serrano himself comes close to such a work with Milk, Blood, 1986. Two vats, one of milk and the other of blood, are photographed butted up against each other. Only the central vertical edges of the glass vats are visible so that the image is abstracted and not dissimilar to some abstract colour field paintings. Serrano's Milk, Blood, while engaging in binary opposites on a visual level, encourages a more diffuse worry. ${ }^{16}$ For Anthony Julius, this work provides an opportunity to reflect on the cultural connotations of bodily substances: 'They are similar: milk nurtures, blood animates. They are different: we ingest milk, we celebrate its flow, we obtain it with a caress; we may not ingest blood (save symbolically, or else to save our lives), we fear its flow, we obtain it painfully, invasively...Like Piss Christ, the work is mediated by photography and presents the same tensions between presentation and substance. We are seduced by the formal, almost minimalist (Rothko) nature of the work but simultaneously confronted by its substance'. 17

Where Kristeva seeks to redeem the body from categories of abomination, Carolyn Bynum Walker's research on the female body and religious practices in the later middle ages (1200-1500) promotes a bodily (incarnational) manifestation of spiritual revelation that, I suggest, avoids binary opposition. ${ }^{18}$ She points to graphic physical processes being revered such as: 'Holy people spat or blew into the mouths of others to effect cures or convey grace. The ill clamoured for the bath water of would-be saints to drink or bathe in, and preferred it if these would-be saints themselves washed seldom and therefore left skin and lice floating in the water. ${ }^{19}$ Following Francis of Assisi, who kissed lepers, several Italian saints ate puss or lice from the poor or sick, thus incorporating into themselves the illness and misfortune of others. ${ }^{20}$ Bynum Walker cautions us against reading into medieval source material an assumption of the binary that control of the body equates to a rejection of sex. She argues that 'Medieval images of the body have less to do with sexuality than with fertility and decay. Control, discipline, even torture of the flesh is, in medieval devotion, not so much the rejection of physicality as the elevation of it - a horrible yet delicious elevation - into a means of access to the divine' ${ }^{21}$

Two sixteenth-century religious paintings support this rejection of the body as abject, and the connection between sexuality and abjection. Leo Steinberg argues that, in Lucas Cranach's Holy Trinity in a Glory of Angels (c.1515-18) and Hans Schaufelein's Crucifixion (1515) (both of which depict Jesus with an erection), the erection is an iconographic symbol of the resurrection. A Dutch painting, the Good Shepherd, c.1550, from the church of St John in Schiedam, has Christ's genitalia as the central focus of the pictorial space. St. Augustus held that involuntary erections were a condition of original sin. Yet, in Christ's 
body, as the New Adam, an erection is willed and intended, a sign of the annulment of sin and death through the resurrection. ${ }^{22}$ To suggest a singularly sexualised reading of such an image from the sixteenth century would be to misread the material, and to fall into the binaries of much contemporary discourse. Just as we do not need to read these binaries into the crucifixion-erection-motif, we may interpret a contemporary Virgin-condom-motif as having to do with fertility and an elevation of physicality as a means of access to the divine.

Mieke Bal explores such a turning of the tables. According to Bal:

The flesh that is so important in the Christian tradition takes on different meanings at different moments in history. From the perspective of an engaging late twentieth century [and now the twenty first century] where pain and suffering are often bound up with sexuality, we are now enabled, by artists who endorse this baroque historiography and the entanglement that characterises it, to scratch away the dust of a disembodied religiosity and gain access again to a religious life that is much closer to bodily experience. ${ }^{23}$

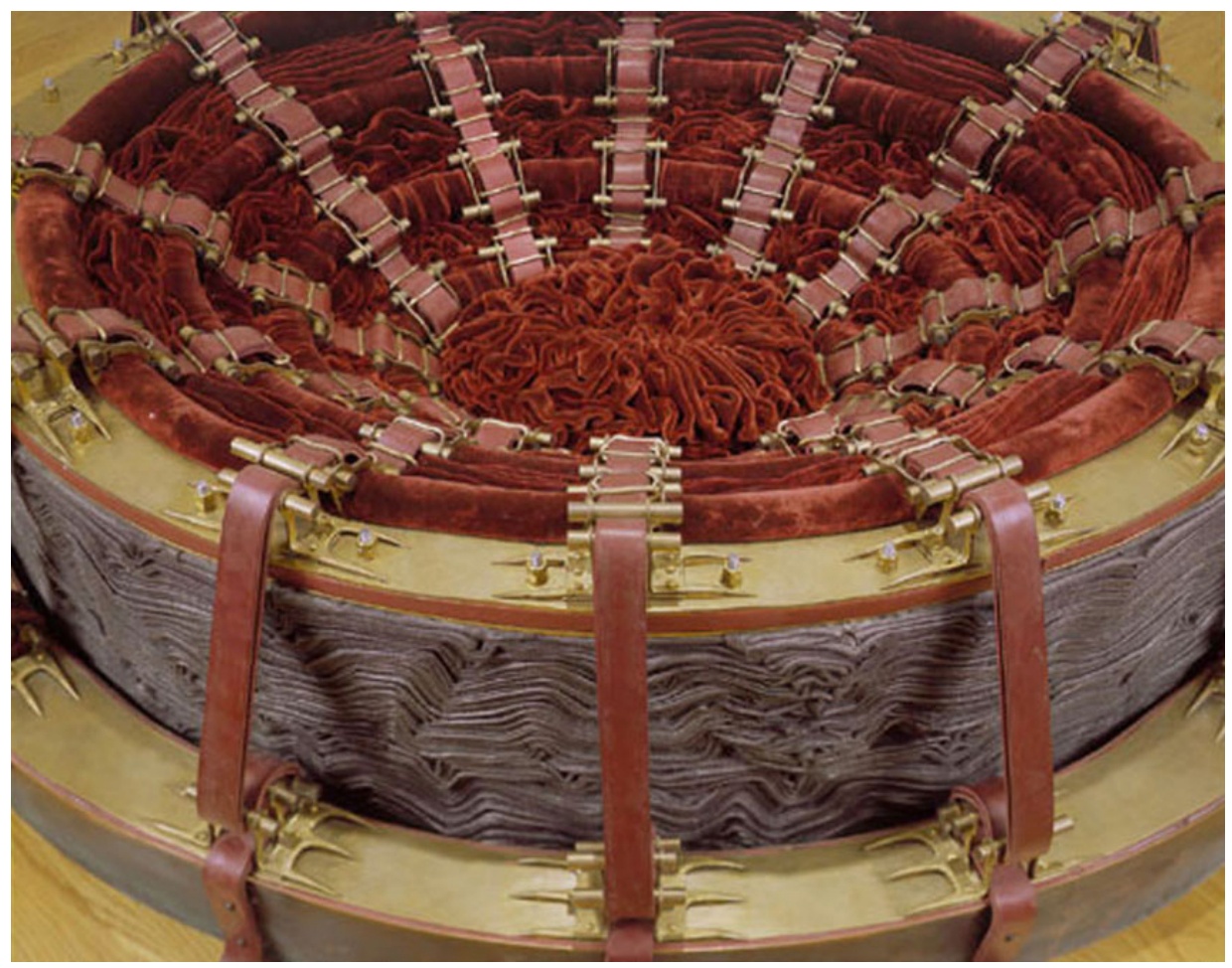

Cathy de Monchaux, Red, 1999, (C) Cathy de Monchaux 
In this light, another work from the Votive exhibition, Red, by Cathy de Monchaux, challenges boundaries of the sacred and profane by adopting mixed messages: heraldic motifs reminiscent of imperially religious crosses and crests, and simultaneously, gynaecological-like instruments of fetish. Red collapses institutional order into private blossomings of flesh. The sculpture is obsessively created. With all the components cut by hand, the detailed clasps, buckles and leather belts tie down, and yet follow the formation of a concentrically descending vulva-like velvet interior. Like Ian Breakwell's The Sermon, there is a strongly public face to this work that nods to ecclesiastical and, in this case, royal protocol. Desires of the flesh are here enfolded, literally and metaphorically, onto the strictures of the law. But what is extraordinarily successful in this work is the manner in which these conflicting elements never overpower each other but are held together as palpable transgression. De Monchaux's Red becomes a powerful sign of the fertile body, the physically disciplined and restrained body and, yes, the sexually engorged body, but the enriched body as signifier of religious life in bodily experience.

Bynum Walker's caution against binary thinking is also helpful in discussing Serrano's work. If it were Christ's piss (like the dirty bath water of would-be saints), would the abject transfer to the realm of the sacred? What would we do with a phial of Christ's piss, other than venerate it? Moreover, does Serrano's photograph of Christ in piss, together with such uplifting and sublime aesthetics, redeem piss from being an ensign of the body's abject nature? In this shift from piss to a photograph of piss I have in mind Rosalind Krauss' argument, in referencing André Bazin's 'The Ontology of the Photographic Image', that photographs, by virtue of their process, are indexically linked to the objects they portray in ways that exceed representation: 'The photographic image is the object itself.' In this way, the photograph, together with its aesthetic qualities, might redeem the abject substance. ${ }^{24}$ The act of pissing on the Koran in war lacks the devotional and aestheticising intentions of both Serrano and Kovats. The meaning of the image Piss Christ is much more complex than the meaning of either pissing on Christ or pissing on a crucifix, just as the meaning of the sculpture Virgin in a Condom is more multifaceted than the significance of comparing the Virgin Mary with an erection. Can we view these works from a position that is beyond the conventional binary of the pure and impure? If we consider the incarnational possibility that Christianity affords, to become as Christ, then Serrano's piss and Christ's piss - Serrano's body and Christ's body - may become as one. In the words of Damian Casey: 'God's place is with the abject every bit as much as it is on the high altar of the cathedral.' ${ }^{25}$ In this light, Piss Christ could be seen as 'an attempt to retrieve the meaning of the incarnation'. ${ }^{26}$ Casey contends that it is Serrano's 'exploration of the relation between the abject and the sacred that makes Piss Christ not only good art, but good religious art, bordering on the iconic' ${ }^{27}$ 
When Bynum Walker cautions a straight forward assumption of binary thinking in medieval source material, she offers us a challenge to re-examine works such as Piss Christ and Virgin in a Condom from perspectives that are not preoccupied with the body as primarily sexual in function, or abject secretions. While both artworks are highly polemical and confrontational - this is piss and this is a condom - both artists deny a singularly blasphemous intent, alluding instead to both devotional and political intention. Both images have historical precedents where body fluids and the body's imagery are not clearly divided between the sacred and the abject. I contend that such historical perspectives inform a richer interpretation of Piss Christ and Virgin in a Condom. Seen from this perspective, these images signify the possibility of divine revelation through the body.

\section{Conclusion}

We cannot rely on a purely conventional understanding of blasphemy in understanding blasphemy in artistic contexts. Intentions matter to our reading of acts of blasphemy and change our perspective on whether they are acceptable. The context of the museum does more than reserve a space for artists to critique outside the realms of worship, but enables the possibility of artists operating across the parameters of critique and devotion. In this sense, the choice to curate Votive: Sacred and ecstatic bodies in museums offered the possibility to interpret Ian Breakwell's Deep Faith and Cathy de Monchaux's Red (and the other art works discussed above) as 'religious' works that operate outside conformist religious structures. In this respect museums and galleries have a role in providing a space for the expression of alternative, and sometimes unconventional, religious expression; offering artists, within certain restrictions, the possibility to articulate what they want. The polemical nature of the abject and sacred common to many of the artworks discussed in this chapter is not new. Contemporary binaries regarding bodily fluids, suffering and flesh are often bound up with sexuality, creating a sense of the religious that is disembodied. It is in a reappraisal of our perceptions of binary imagery (misunderstood by essentialist religious paradigms) that a solution emerges. Bynum Walker's research into medieval perceptions of the abject body as less sexual and more to do with fertility and decay indicate that the time at which something is viewed changes our understanding of whether blasphemy has occurred. It may be, that from the perspective of contemporary religious authority, these images are blasphemous, however, historical readings of the body in religious art make us question whether we must view works such as Piss Christ and Virgin in a Condom in this fashion. These works operate within a framework that is more complex than a conventional reading of blasphemy allows. They may also be interpreted as devotional, religious expressions. 


\section{Endnotes}

${ }^{1}$ While the work of these artists provoked the greatest outcry, such juxtapositions of the sacred and profane are also characteristic of the work of Ian Breakwell and Cathy de Monchaux discussed later in this chapter in the context of the exhibition Votive: Sacred and ecstatic bodies.

2 The exhibition Votive: Sacred and ecstatic bodies toured two venues in New Zealand, the Adam Art Gallery of Victoria University, Wellington, and the Dunedin Public Art Gallery, finishing in 2002. The project was collaboratively curated by Mark Jackson as writer/curator and myself as artist/curator and I acknowledge Mark Jackson's assistance in thinking through many of the issues in this chapter as well as Mel Hight, postgraduate candidate at AUT University. Votive responded to controversy surrounding Tania Kovat's exhibit Virgin in a Condom at the Museum of New Zealand Te Papa Tongarewa in 1998. Votive included works by: Ian Breakwell and Cathy de Monchaux (Britain); Pierre and Gilles (France); Megan Jenkinson and myself (New Zealand). In choosing the works for Votive, we attempted to encourage thinking beyond the binary of 'right wing fundamentalism' versus 'freedom of speech' and an environment respectful of differences of opinion.

${ }^{3}$ Kyla McFarlane, 2002, 'Incisions and Excesses', in Votive: Sacred and Ecstatic Bodies, Wellington and Dunedin: Adam Art Gallery and Dunedin Public Art Gallery, pp. 10-19, at p. 10

4 McFarlane, ibid., note 2.

5 'Piss Christ exhibition 97.4', The Arts Law Centre of Australia, http://www.artslaw.com.au/reference/piss974/ (Viewed 27 April 2004.)

6 Ibid.

7 McFarlane, op. cit., note 2.

8 'Anger over Virgin in a condom art' 1998, Dispatch Online, http://www.dispatch.co.za/1998/03/11/foreign/condom.htm. (Viewed 20 December 2005.)

9 Damien Casey, 2000, 'Sacrifice, Piss Christ, and liberal excess', p. 2, http://dlibrary.acu.edu.au/staffhome/dacasey/Serrano.html. (Viewed 20 December 2005.)

10 Stephen Davies, 1991, 'Dickie's Institutional Theory of the Definition of Art', in Definitions of Art, Ithaca, N.Y. Cornell University Press, pp. 78-114, at pp. 83-84.

11 McFarlane, op. cit., note 2, p. 13.

12 Curated by Bruce Fergusson and Sarah Olsen.

13 McFarlane, op. cit., note 2.

14 Julia Kristeva, 1982, Powers of Horror: An Essay on Abjection, Columbia: Columbia University Press, p. 94.

15 Ibid., p. 109.

16 Anthony Julius, 2002, Transgressions: The Offences of Art, London: Thames and Hudson, p. 139.

17 Ibid.

18 Carolyn Bynum Walker, 1992, Fragmentation and Redemption: Essays on Gender and the Human Body in Medieval Religion, New York: Zone Books, p. 162.

19 Ibid., p. 163.

20 Ibid.

21 Ibid., p. 162.

22 Steinberg, Leo 1996, The Sexuality of Christ in Renaissance Art and in Modern Oblivion, Chicago: The University of Chicago Press, pp. 318-324.

23 Mieke Bal, 1999, Quoting Caravaggio: Contemporary Art, Preposterous History, Chicago: The University of Chicago Press, p. 38, cited by McFarlane, op. cit., note 2.

24 Rosalind Krauss, 1986, The Originality of the Avant-Garde and Other Modernist Myths, Cambridge, Mass: MIT Press, p. 203.

25 Casey, op. cit., p. 3.

26 Ibid., p. 6.

27 Ibid., p. 2. 